\title{
Peculiar phenomena regarding climatic and glacial variations on the Tibetan Plateau
}

\author{
Yafeng SHI, Shiyin LIU, Donghui SHANGGUAN, Donglian LI, Baisheng YE
}

Key Laboratory of Cryosphere and Environment, Cold and Arid Regions Environmental and Engineering Research Institute, Chinese Academy of Sciences, 260 Donggang Road, Lanzhou 730000, China

E-mail: liusy@Izb.ac.cn

\begin{abstract}
In contrast to the worldwide intensive warming and consequent glacier shrinkage during the last 30 years, two peculiar phenomena have been observed on the Tibetan Plateau: (1) the temperature has decreased about $0.6^{\circ} \mathrm{C}$ on the northern Tibetan Plateau, with smaller than average glacier retreat and meltwater discharge, and (2) a number of glaciers have been advancing on the southeast Tibetan Plateau in response to increased precipitation. These observations indicate the complex nature of the response of glaciers to climate changes.
\end{abstract}

\section{INTRODUCTION}

Recent global-scale warming has been attributed primarily to the rapid increase of anthropogenic greenhouse emissions (Houghton and others, 2001). The global mean temperature has risen by about $0.6^{\circ} \mathrm{C}$ since 1860 , and an especially dramatic warming of about $0.5^{\circ} \mathrm{C}$ has occurred during the 1970s-90s. Such warming appears to be more prominent between latitudes $40^{\circ} \mathrm{N}$ and $70^{\circ} \mathrm{N}$ (Houghton and others, 2001). However, mean temperatures on the northern Tibetan Plateau, as derived from an ice-core record, appear to have dropped $0.6^{\circ} \mathrm{C}$ during the same period, and many glaciers in the region have shown little change. Except for Antarctica, glacier retreat has recently been a dominant large-scale phenomenon. In western China, $>80 \%$ of the glaciers are retreating, with a reduction in area of about $4-5 \%$ over the past four decades (Ding and Liu, 2006). Conversely, a number of glaciers ( $>40 \%$ of those observed) in part of the southeast Tibetan Plateau have been advancing in the last 20 years (Liu and others, 2006). Here we explore these two peculiar phenomena in detail.

\section{IMPACT OF DECLINING TEMPERATURES ON GLACIER AND MELTWATER CHANGES ON THE NORTHERN TIBETAN PLATEAU}

The main part of the northern Tibetan Plateau includes the western and central Kunlun Shan and the northern Qiangtang Plateau (roughly $32-37^{\circ} \mathrm{N}, 75-95^{\circ} \mathrm{E}$; Fig. 1). The Kunlun Shan are known as the backbone of Asia, extending from west to east, with wide mountain ranges mostly higher than 6000 ma.s.l. and the highest peak at $7167 \mathrm{~m}$ a.s.l. The high and broad mountains and prevailing climate provide favorable conditions for glacier development at present. According to the China Glacier Inventory (CGI), glaciers in the western and central Kunlun Shan cover $12136 \mathrm{~km}^{2}$, and the equilibrium-line altitude (ELA) ranges between 480 and $6200 \mathrm{~m}$. There are several isolated mountains in the northern Qiangtang Plateau with eroded surfaces above $6000 \mathrm{~m}$ a.s.l., and some isolated interior lake basins. In this region, glaciers cover an area of about $1500 \mathrm{~km}^{2}$, with the ELA ranging from 5300 to $6100 \mathrm{~m}$.

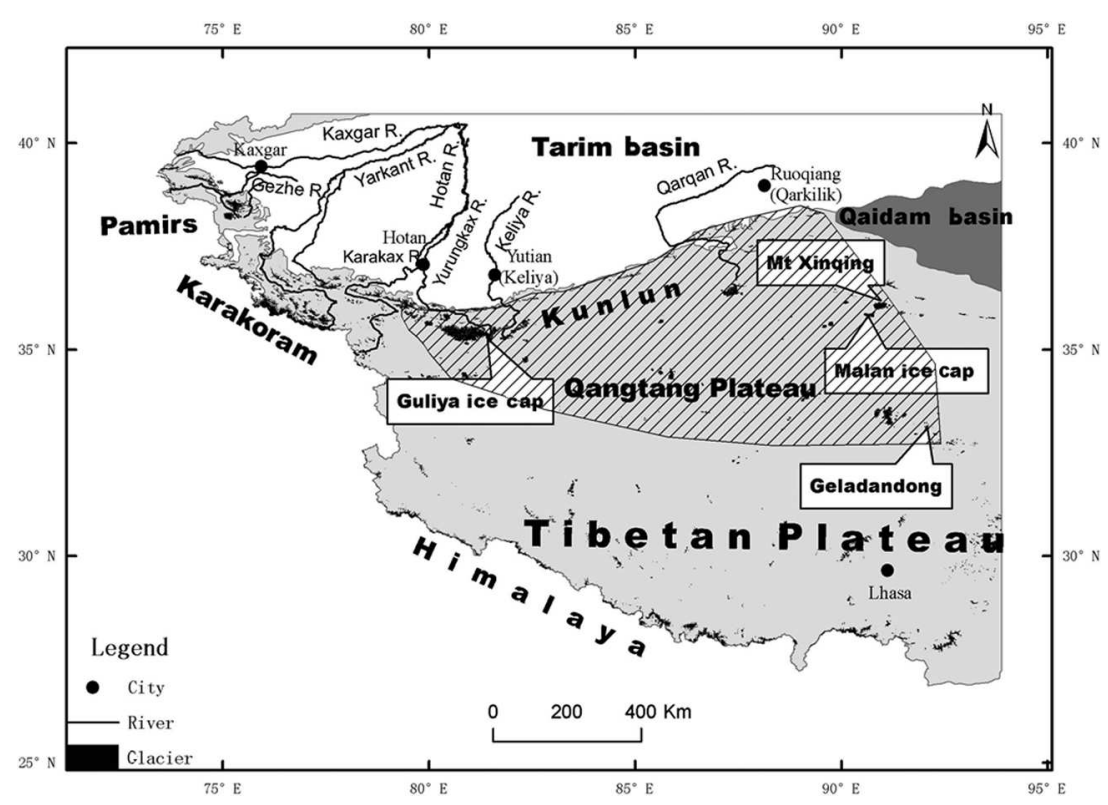

Fig. 1. Sketch map showing the regions where temperatures have declined in the northern Tibetan Plateau (hatched area) and the locations of ice cores and rivers discussed in this paper. 


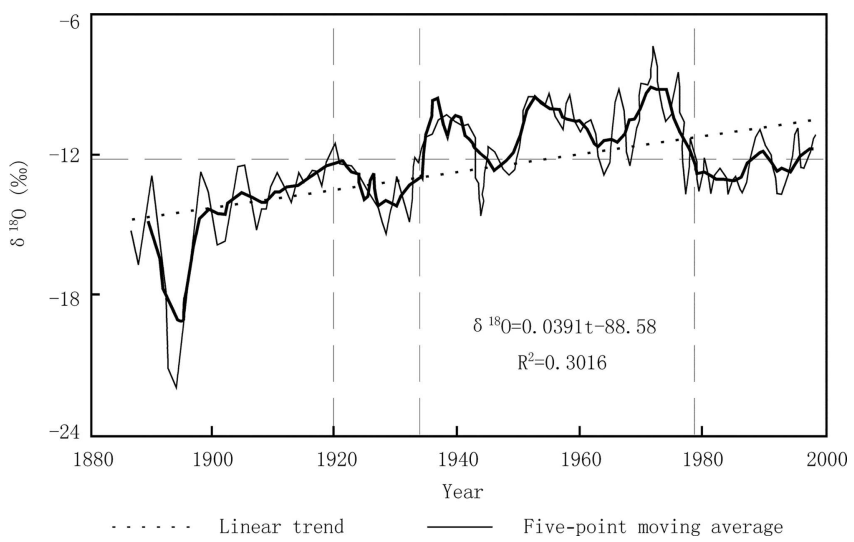

Fig. 2. The temperature in the summer half of the year as inferred from $\delta^{18} \mathrm{O}$ recorded in an ice core from the Malan ice cap (Wang and others, 2003).

The climate in this region is extremely cold and dry. Using some short time observations and proxy data, we estimate that the annual precipitation at the ELA ranges from 200 to $500 \mathrm{~mm}$, and the mean annual and summer temperatures are below $-10^{\circ} \mathrm{C}$ and $-1{ }^{\circ} \mathrm{C}$, respectively. These glaciers are classified as the extreme continental type or polar type (Shi and Liu, 2000), being less responsive to climate change. From the end of the Little Ice Age to the mid-20th century, the total glacial area across 12 separate mountains in the Qiangtang Plateau has decreased from an estimated $1487 \mathrm{~km}^{2}$ to $1406 \mathrm{~km}^{2}$, a decrease of $5.5 \%$ (Pu and others, 2004). However, the temperature increase during this period is estimated to have been as high as $1-2^{\circ} \mathrm{C}$.

The temperature for the summer half of the year, revealed by $\delta^{18} \mathrm{O}$ recorded in an ice core taken from the Malan ice cap $\left(35^{\circ} 50^{\prime} \mathrm{N}, 90^{\circ} 40^{\prime} \mathrm{E} ; 6056 \mathrm{~m}\right.$ a.s.l.), showed a rise of about $1.2^{\circ} \mathrm{C}$ during the past century, double that of the global mean change as illustrated in Figure 2. However, a temperature decrease of approximately $0.6^{\circ} \mathrm{C}$ occurred during the 1970s-90s, in contrast to the general globalscale warming over the period (Wang and others, 2003).

The radiosonde data at Ruoqiang meteorological station on the north slope of the western Kunlun Shan indicate that the altitude of the $0^{\circ} \mathrm{C}$ isotherm in the atmosphere has decreased by about $100 \mathrm{~m}$ between the 1970s and 1990s (Fig. 3) (Zhang and others, 2005), corresponding to a decrease of about $0.6{ }^{\circ} \mathrm{C}$ in temperature. When combined with the Malan ice-core record, the area experiencing temperature decrease may in fact be quite large within this region of the northern Tibetan Plateau.

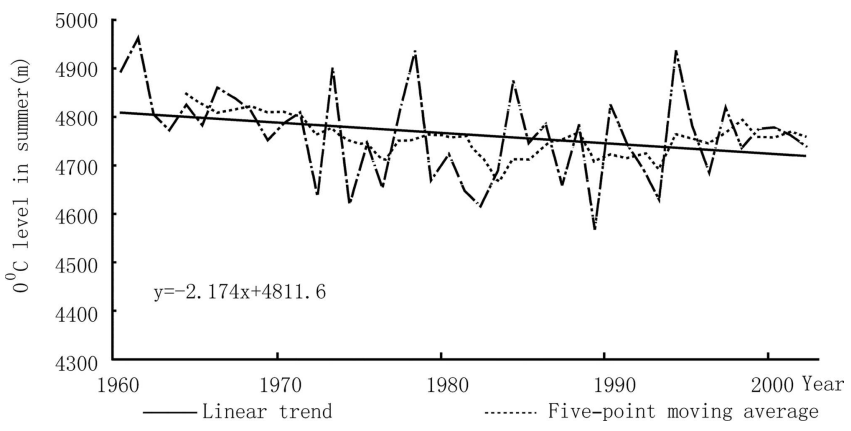

Fig. 3. The radiosonde altitude of the $0^{\circ} \mathrm{C}$ isotherm at the Ruoqiang meteorological station (Zhang and others, 2005).

Further evidence comes from satellite imagery and here we summarize the results published by different authors. Their data were mainly based on Landsat Thematic Mapper (TM) and Enhanced Thematic Mapper Plus (ETM+) images around 2000 and upon topographical maps made before the 1970s (Table 1).

As clearly shown in Table 1, glaciers in the region have experienced little change, with a reduction of $0.8 \%$ in area during the past 30 years, and the Malan ice cap has even expanded by $1.2 \%$. The smaller changes in glacier area in this region might reflect reduced ablation due to lower air temperatures. The Geladandong mountains are situated at the northwestern end of the Tanggula range, outside the northern Tibetan Plateau, and show a $1.6 \%$ decrease in area. Whether these changes are driven by a colder climate or other causes is a question that needs additional research.

Several rivers in the southern part of the Tarim basin are mainly supplied by meltwater of the glaciers in the west Kunlun Shan. Changes in stream discharge are directly related to climate change and the sensitivities of the glaciers' response to those changes. Observations indicate an increase in stream discharge of most tributary rivers of the Tarim river basin has occurred during the past two decades, because of a significant increase of precipitation and intense melting of glaciers (Shi and others, 2003). However, the runoff of rivers like the Gaizhe, Karakax, Yurunkax and Keriya, originating in the east Pamirs and the west Kunlun Shan, has decreased as shown in Table 2.

Table 2 shows that the stream discharges of these four large glacierized rivers have decreased by about $6 \%$ during the period 1980-2000 relative to the 1951-79 mean discharge. We included the stream discharge data of the Gaizhe river in the northern part of the east Pamirs to suggest

Table 1. Glacier changes in a representative area of the northern Tibetan Plateau

\begin{tabular}{|c|c|c|c|c|c|c|c|}
\hline \multirow[t]{2}{*}{ Location } & \multirow[t]{2}{*}{ Period } & \multirow[t]{2}{*}{ Number of glaciers } & \multirow{2}{*}{$\begin{array}{c}\text { Glacier area } \\
\mathrm{km}^{2}\end{array}$} & \multicolumn{2}{|c|}{ Area change } & \multicolumn{2}{|c|}{ Number of advancing glaciers } \\
\hline & & & & $\mathrm{km}^{2}$ & $\%$ & & $\%$ \\
\hline Yurungkax ${ }^{*}$ & 1970-2001 & 387 & 1776.96 & -4.94 & -0.3 & 3 & 0.8 \\
\hline Xingen mountain ${ }^{\dagger}$ & 1971-2001 & 64 & 419.9 & -7.38 & -1.8 & 16 & 25 \\
\hline Malan mountain ${ }^{\dagger}$ & 1976-98 & 65 & 81.48 & +0.98 & +1.2 & 38 & 59 \\
\hline Geladandong mountain ${ }^{\ddagger}$ & 1969-2000 & 253 & 915.7 & -15.7 & -1.6 & 1 & 0.4 \\
\hline Total & & 756 & 3194.04 & -26.44 & -0.8 & 58 & 7.7 \\
\hline
\end{tabular}

Data source: *Shangguan and others (2004); 'Liu and others (2004); *Yang and others (2003). 


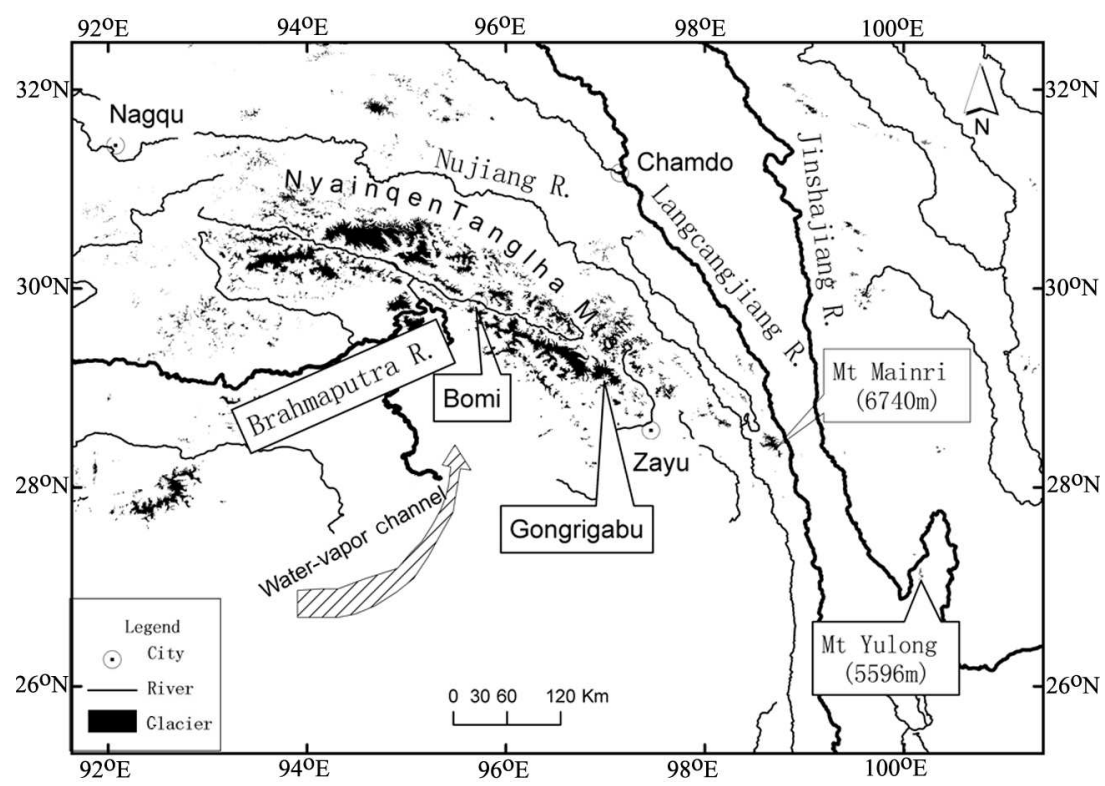

Fig. 4. Sketch map showing the location of the Gangrigabu range and the main monsoon passage over the southeast Tibetan Plateau.

that the zone of decreasing temperatures may extend westward into part of the northern Pamir plateau. An important question is: why is the change of discharge for the Keliya river the smallest among the four rivers? We believe that this may be the result of a cold period during the 1990s in the glacierized source area of this river. This river originates on the north slope of the Guliya ice cap, where records of $\delta^{18} \mathrm{O}$ and net accumulation rate taken from an ice core extracted at an altitude of $6200 \mathrm{~m}$ in 1992 indicated a slight decrease in temperature and a relatively strong increase in accumulation occurred between 1975 and 1991 (Yao and others, 1995). The combined changes of lower temperature and increased accumulation might explain, at least in part, the smaller stream discharges of the Keriya river.

In summary, an apparent temperature decrease of about $0.6^{\circ} \mathrm{C}$ occurred during the late 1970 s to 1990 s over a large area, possibly extending $1200 \mathrm{~km}$ from east to west in the northern Tibetan Plateau. This period of lower temperatures could certainly have prevented the shrinkage of glaciers with a total area reduction of $<1 \%$, which contributed to the decrease of about $6 \%$ in the stream discharges in glacierized rivers on the south side of the Tarim basin over the last three decades.

Table 2. Changes in the stream discharge for four tributary rivers in the southern part of the Tarim basin

\begin{tabular}{lrcccc}
\hline River & $\begin{array}{c}\text { Drainage } \\
\text { area }\end{array}$ & $\begin{array}{c}\text { Glacier } \\
\text { area }\end{array}$ & \multicolumn{2}{c}{ Mean runoff } & $\begin{array}{c}\text { Rate } \\
\text { change }\end{array}$ \\
& & & $1951-79$ & $1980-2000$ & \\
& $\mathrm{~km}^{2}$ & $\mathrm{~km}^{2}$ & $\mathrm{~m}^{3} \mathrm{~s}^{-1}$ & $\mathrm{~m}^{3} \mathrm{~s}^{-1}$ & $\%$ \\
\hline Gaizhe & 9753 & 1451 & 31.02 & 28.71 & -7.3 \\
Karakax & 50248 & 2557 & 69.03 & 66.06 & -4.4 \\
Yurunkax & 14575 & 2958 & 72.58 & 65.91 & -9.6 \\
Keriya & 7538 & 1357 & 22.22 & 21.99 & -1.1 \\
Total & 82114 & 8323 & 194.85 & 182.67 & -6.2 \\
\hline
\end{tabular}

\section{POSSIBLE CAUSES OF GLACIER ADVANCES IN PART OF THE SOUTHEAST TIBETAN PLATEAU}

Glaciers in the southeast Tibetan Plateau and the Hengduan Shan are influenced by the southern Asian monsoon climate, from which abundant moisture is transported into this region. These glaciers are characterized by high accumulation and intensive ablation, relatively high ice temperatures, basal sliding and rapid movement of ice masses. The Gangrigabu range, with a highest peak of $6610 \mathrm{~m}$ a.s.l., is located to the south of $30^{\circ} \mathrm{N}$ and close to the grand $\mathrm{U}$ shaped turn of the Yalung Zangbo river, on the upper reach of the Brahmaputra river. This river channel is considered to be one of the main passages for the Indian monsoon currents (Fig. 4). The annual precipitation at the ELA is estimated to be $2500-3000 \mathrm{~mm}$, inferred from the annual net accumulation and precipitation gradients (Shi and Bai, 1988). The ELA of glaciers in the region decreases to about $4700 \mathrm{~m}$, much lower than the $\sim 6000$ m elevation of the ELA on the north slope of the central Himalaya (Xie and Feng, 2002). According to the $\mathrm{CGl}$, there are 1320 glaciers with a total area of $2655 \mathrm{~km}^{2}$ and a total ice volume of $260 \mathrm{~km}^{3}$. Using Landsat TM imagery acquired in 1999 and China-Brazil Earth Resources Satellite (CBERS) imagery from 2001 geometrically corrected to topographical maps from 1980, Liu and others (2006) found that 102 measured glaciers in the region had all retreated between 1920 and 1980, with a total area reduction of $47.9 \mathrm{~km}^{2}$, or $4.3 \%$ of the area in the $1920 \mathrm{~s}$. For the 88 monitored glaciers with change measurements during 1980 and 2001, 52 glaciers, or $59 \%$ of these glaciers, with a total area of $797.78 \mathrm{~km}^{2}$ in 1980 , were retreating as revealed by a 2001 CBERS image; the remaining 36 glaciers, or $41 \%$ of the 88 observed glaciers, had advanced since 1980. This resulted in a total area decrease of $2 \mathrm{~km}^{2}$, or only $0.25 \%$ of the area of the 88 glaciers, since 1980 . Liu and others have discussed length changes of individual glaciers, which can be compared with records of other observed glaciers in the southern part of the Hengduan Shan. Table 3 summarizes these changes in glacier length.

All seven of the glaciers are located within the region 28$30^{\circ} \mathrm{N}, 95-101^{\circ} 30^{\prime} \mathrm{E}$ and are under the strong influence of 
the Indian monsoon. The number of advancing glaciers and the large amplitude of glacier length changes cannot be solely explained by the recent climatic warming. The mean summer temperature (May-September) during the period 1960-2002 has risen by $0.3^{\circ} \mathrm{C}$ at Zayu ( $2331 \mathrm{~m}$ a.s.I.) and by $0.5^{\circ} \mathrm{C}$ at Bomi (2737 $\mathrm{m}$ a.s.I.). These two stations are close to the Gangrigabu range. Figure 5 shows an anomalous annual precipitation increase at Bomi of $40 \mathrm{~mm}$ in the 1960s, culminating in levels $20 \mathrm{~mm}$ above normal in the 1980s and 1990s, though a slight decrease is observed at Zayu. These observations reflect the large disparity in precipitation between these stations separated by only about $230 \mathrm{~km}$, showing the importance of local and regional variability in mountain regions. Although differences in precipitation changes exist at the local scale, the precipitation increase between 1971 and 2000 was more prominent at the regional scale of the Tibetan Plateau (Wu and others, 2005). Wu and others indicated that $69 \%$ of the 77 meteorological stations on the Tibetan Plateau have experienced a precipitation increase from 1971 to 2000.

As mentioned above, annual precipitation at the ELA of glaciers may be as much as $2500-3000 \mathrm{~mm}$. If the year-toyear anomalies in precipitation range $20 \%$ above or below the mean, this translates into annual precipitation values of $500-600 \mathrm{~mm}$. Such large variability in precipitation certainly exerts a strong impact on glacial behavior which in turn emphasizes that changes in precipitation play a more important role, at least in the short term, on glacier behavior in this region than does a slight rise in air temperature. For example, a number of glaciers were advancing in western Norway up until 1999 and this was attributed to increases in winter precipitation as a result of the positive phase of the North Atlantic Oscillation (Houghton and others, 2001). However, since 1999 most of the Norwegian glaciers have been retreating as regional temperatures have continued to increase (personal communication from L.G. Thompson, 2006). We speculate that the irregular increase of precipitation, apparent in the Bomi record, has led to an increase in accumulation. At the same time, the ablation on many of these glaciers has declined

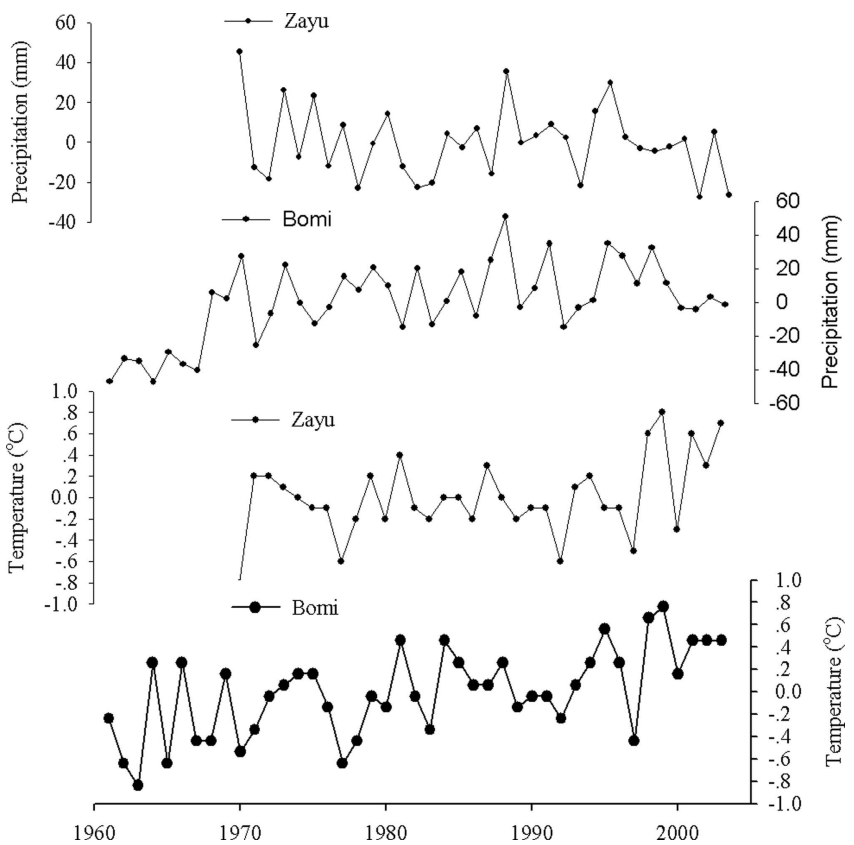

Fig. 5. Annual precipitation anomalies (upper two panels) and annual mean air-temperature anomalies (lower two panels) at the Zayu and Bomi meteorological stations, respectively.

and these changes result in increased kinematic wave velocities and basal sliding. The result is an increase in the ice mass flux to the glacier terminus which is expressed as a glacier advance. Although we cannot estimate the amount and timing of increasing precipitation, the combined effects of the increase in precipitation and meltwater discharge increase the frequency of disasters like avalanches, debris flows, landslides and mountain floods. For example, a large debris flow occurred in Guxiang village, Bomi, on 30 July 2005, caused by the rapid increase of glacial ablation, and interrupted traffic along the Sichuan-Tibet highway for several days.

Table 3. Length changes of some large glaciers in the Gangrigabu range and other local mountains

\begin{tabular}{|c|c|c|c|c|c|}
\hline Glacier name & $\begin{array}{l}\text { Length } \\
\text { km }\end{array}$ & $\begin{array}{l}\text { Area } \\
\mathrm{km}^{2}\end{array}$ & Period & $\begin{array}{l}\text { Length change } \\
\text { m }\end{array}$ & $\begin{array}{c}\text { Area change } \\
\mathrm{km}^{2}\end{array}$ \\
\hline Nalung & 32.5 & 191.4 & 1980-2001 & -1534 & -2.23 \\
\hline \multirow[t]{3}{*}{ Azha } & 16.7 & 13.75 & $1920-30^{*}$ & in advance & \\
\hline & & & $1933-80^{*}$ & -995 & -0.44 \\
\hline & & & 1980-2001 & -1627 & \\
\hline $5 \mathrm{O} 282 \mathrm{~B} 0099^{\S}$ & 7.7 & 21.55 & 1980-2001 & -920 & \\
\hline $5 \mathrm{O} 282 \mathrm{~B} 0123^{\S}$ & 6.1 & 22.81 & 1980-2001 & +1762 & +0.49 \\
\hline $5 \mathrm{O} 282 \mathrm{~B} 0136^{\S}$ & 4.5 & 12.63 & 1980-2001 & +1117 & +0.51 \\
\hline \multirow[t]{5}{*}{ Melang glacier, Mainri mountain ${ }^{\dagger}$} & 11.7 & 12.55 & $1932-59$ & $\sim-2000$ & \\
\hline & & & 1959-71 & +830 to $930^{*}$ & \\
\hline & & & $1971-82$ & +70 & \\
\hline & & & 1982-98 & +280 & \\
\hline & & & 1998-2002 & -30 & \\
\hline & & & 1957-92 & +800 & \\
\hline & & & 1992-2002 & -250 & \\
\hline
\end{tabular}

${ }^{*}$ Su and Li (1996); ${ }^{\dagger}$ Zheng and others (1999); ${ }^{*}$ He and others (2003); ${ }^{\S}$ Liu and others (2006). 


\section{CONCLUSIONS}

The two peculiar or abnormal phenomena of glacier variation and climate change described in this paper highlight the complexity of glacier responses to climate change. Previous studies (e.g. Shi and Liu, 2000; Yao and others, 2004), which have estimated the scale of glacier reduction as primarily a response to rising temperatures, have neglected the impact of changes in precipitation. Over the northern Tibetan Plateau, the period of cooler temperatures that occurred during the late 1970s to 1990s, along with perhaps a slight increase of precipitation, is likely to have greatly slowed the ongoing glacier retreat and led to prominent meltwater reductions in this region. In the heavier-monsoon-precipitation regions of the southeast Tibetan Plateau such as the Gangrigabu range, the possible increase of precipitation may well have led to the observed glacier advances and slowed the rate of retreat of other glaciers. The reduced rate of loss of total glacier area, along with the increase in precipitation if sustained over time, may result in an increased frequency of natural disasters related to glacial activity. The cool event in the northern Tibetan Plateau discussed in this paper is unlikely to be sustained for very many years into the future as the global-scale warming of the Earth continues. Documenting precipitation increases and the glacier responses to those increases, as well as further addressing the causes of local and regional climate variations on the Tibetan Plateau, is an important area for future research.

\section{ACKNOWLEDGEMENTS}

The authors are grateful to L. Thompson, E. MosleyThompson, $\mathrm{H}$. Brecher and two anonymous reviewers for valuable comments and suggestions, and improvements to the English. This research was financially supported by the Chinese Academy of Sciences (grant Nos. KZCX3-SW-345, KZCX3-SW-339 and 2004102) and the National Natural Science Foundation of China (grants 90202013 and 40371026).

\section{REFERENCES}

Ding, Y. and S. Liu. 2006. The retreat of glaciers in response to recent climate warming in western China. Ann. Glaciol., 43 (see paper in this volume).

He, Y., Z. Zhang, W.H. Theakstone, T. Chen, T. Yao and H. Pang. 2003. Changing features of the climate and glaciers in China's monsoonal temperate glacier region. J. Geophys. Res., 108(D17), 4530. (10.1029/2002JD003365.)

Houghton, J.T. and 7 others. 2001. Climate change 2001: the scientific basis. Contribution of Working Group I to the Third Assessment Report of the Intergovernmental Panel on Climate Change. Cambridge, etc., Cambridge University Press.
Liu, S. and 8 others. 2004. Variation of glaciers studied on the basis of RS and GIS - a reassessment of the changes of the Xinqingfeng and Malan Ice Caps in the Northern Tibetan Plateau. J. Glaciol. Geocryol., 26(3), 244-252. [In Chinese.]

Liu, S. and 8 others. 2006. Glacier changes during the past century in the Gangrigabu mountains, southeast Qinghai-Xizang (Tibetan) Plateau, China. Ann. Glaciol., 43 (see paper in this volume).

Pu, J.C., T.D. Yao, N.L. Wang, Z. Su and Y. Shen. 2004. Fluctuations of the glaciers on the Qinghai-Tibetan Plateau during the past century. J. Glaciol. Geocryol., 26(5), 517-522. [In Chinese with English summary.]

Shangguan, D., S. Liu, Y. Ding, L. Ding and G. Li. 2004. Glacier changes at the head of Yurungkax River in the West Kunlun Mountains in the past 32 years. Acta Geogr. Sin., 59(6), 855862. [In Chinese with English abstract.]

Shi, Y. and C. Bai. 1988. Geomorphologic and climatic conditions of existence of Alpine glaciers in West China. In Shi, Y., M. Huang and B. Ren, eds. An introduction to the glaciers in China. Beijing, Science Press. [In Chinese.]

Shi, Y. and S. Liu. 2000. Estimation of the response of glaciers in China to the global warming in the 21 st century. Chinese Sci. Bull., 45(7), 668-672. [In Chinese.]

Shi, Y., and 6 others. 2003. Discussion on the present climate change from warm-dry to warm-wet in Northwest China. Quat. Sci., 23(2), 152-164. [In Chinese with English abstract.]

$\mathrm{Su}$, Z. and J. Li., eds 1996. Glaciers in Hengduanshan Range. Beijing, Science Press. [In Chinese with English summary.]

Wang, N., T. Yao, J. Pu, Y. Zhang, W. Sun and Y. Wang. 2003. Variations in air temperature during the last 100 years revealed by $\delta^{18} \mathrm{O}$ in the Malan ice core from the Tibetan Plateau. Chinese Sci. Bull., 48(19), 2134-2138.

Wu, S., Y. Yin, Z. Du and Y. Yang. 2005. Climate changes in the Tibetan Plateau during the last three decades. Acta Geogr. Sin., 60(1), 3-11. [In Chinese with English abstract.]

Xie, Z. and Q. Feng. 2002. Distribution characteristics of existing glaciers in the Ganges-Yarlung Zangbo drainage basin and its utilization prospect. In Mi, D. and Z. Xie, eds. Glacier inventory of China: the Ganga drainage basin (XI) and Indus River (XII). $X_{i}$ an, Xi'an Cartographic Publishing House, 9-47. [In Chinese.]

Yang, J., Y. Ding, R. Chen, S. Liu and A. Lu. 2003. Causes of glacier change in the source regions of the Yangtze and Yellow rivers on the Tibetan Plateau. J. Glaciol., 49(167), 539-546.

Yao, T., K. Jiao, L. Tian, K. Jiao, Z. Yang and W. Shi. 1995. Climatic variations since the Little Ice Age recorded in the Guliya ice core. Sci. China D, 39, 588-596. [In Chinese.]

Yao, T.D., Y.Q. Wang, S.Y. Liu, J.C. Pu, Y.P. Shen and A.X. Lu. 2004. Recent glacial retreat in High Asia in China and its impact on water resource in Northwest China. Sci. China D, 47, 1065-1075.

Zhang, G., Y. Lianmei and Y. Qing. 2005. Change trend and abrupt change of $0^{\circ} \mathrm{C}$ level height in summer in Xinjiang from 1960 to 2002. J. Glaciol. Geocryol., 27(3), 376-380. [In Chinese with English abstract.]

Zheng, B., X. Zhao, T. Li and C. Wang. 1999. Features and fluctuation of the Melang glacier in the Mainri mountain. J. Glaciol. Geocryol., 21(2), 145-150. [In Chinese with English abstract.] 